\title{
SOCIAL REINTEGRATION OF PARAPLEGICS AND TETRAPLEGICS IN THE CAPE PROVINCE OF THE REPUBLIC OF SOUTH AFRICA
}

\author{
By A. G. Key, M.B.Ch.B.(Cape Town) and S. M. Hurford, B.Soc.Sc., B.A.Hons.(S/W) \\ Spinal Unit, Conradie Hospital, Pinelands, Cape Province Cripple Care Association
}

(Western Cape)

\begin{abstract}
Successful total rehabilitation should include achieving maximum function and satisfaction in life outside the hospital. The disabled person has to learn to deal with a world designed for, and dominated by, able-bodied persons not very accepting of those with disabilities. Access to buildings and recreational facilities are the main obstacles. Despite these problems, achievement in many instances has been remarkable. Assistance with social reintegration and adaptation is provided for in South Africa by State departments, provincial and local authorities and private welfare organisations.
\end{abstract}

Key words: Spinal cord injury; Total rehabilitation; Social reintegration; State, provincial and local authority provisions.

\section{Introduction}

THE social reintegration of the spinal cord injury patient must be regarded as a part of the ongoing rehabilitation programme which commences in hospital as a dynamic process from the very first day post injury. Rehabilitation has been defined as 'the process of learning to live with one's disability in one's own environment' (R. B. Trieschmann). Traditionally it has been focused on teaching techniques of mobility, activities of daily living and new vocational skills that will achieve the greatest possible degree of independence. Successful total rehabilitation should include, not only attaining maximum function, but also satisfaction in life outside the hospital. This of necessity requires that a goal in life is desired and striven for, and that the focus is on what the person can do, and not what he cannot do.

It is becoming increasingly apparent, to us in the Western Cape, that the disabled themselves are now striving to overcome the problems that face them. They are actively participating in the organisations designed to assist them with their reintegration into society, which up to now have been predominantly ablebodied in structure. As the number of potentially employable disabled persons has increased, the need to provide facilities that will allow them to lead a full and active life have become apparent.

We do not as yet have legislation that demands that employers take on a certain percentage of disabled employees on their establishment. There are however an increasing number of business organisations who are very cooperative and willing and who do employ disabled people. Our main problems are:

(I) Access to buildings and recreational facilities.

(2) Transport.

(3) Parking privileges. 
In order to provide the training for an occupation that will lead to employment, available in a building that is fully accessible and with no transport or parking problems is indeed at present a somewhat limited Utopia. Access is improving, as evidenced by the more frequent appearance of the international wheelchair sign on buildings. Disabled who do not have their own private transport have been assisted by the introduction of flexi-time by some firms, which enables them to use public transport out of peak hours. Those with their own cars, requiring conversion to hand control, now have access to a number of relatively inexpensive conversions designed by several enterprising motor companies and individuals in Cape Town. These are simple and effective and do not alter the car's normal drivability.

Our city council have agreed to issue parking meter hoods to disabled who qualify for privileged parking, which has helped considerably.

These modest steps forward, relate only to making suitable employment practical-the rest has yet to come. Life is not all work and no play. Access to public buildings and recreational facilities has yet a long way to go, but as the tax-paying members of our community increase in number, their rights for equal opportunities must be met.

Despite the hurdles and obstacles that we, as a society create, achievement in a number of instances has been quite remarkable.

\section{Examples:}

(I) A young I9-year-old 2nd year medical student who sustained a T9 complete paraplegia in a motor accident, decided that he wished to complete his medical education. He was faced with a medical school built on the slopes of Devil's Peak mountain. A complex of multi-storied buildings with numerous flights of stairs and no lifts. This did not deter him, he approached the authorities, temporary ramps were built and he returned to his studies. His fortitude and academic achievement led to an awareness that facilities should be incorporated for others like him, permanent ramps have been installed at the University of Cape Town Medical School. These ramps have proved to have other practical uses-heavy equipment is now much more easily transported into these buildings! This young man is now an anaesthetic registrar at a hospital in the Eastern Province. One of the consultants teaching him is herself in a wheelchair.

(2) A C 5 complete tetraplegic, as result of a rugby injury when he was 17 years old, is now employed on a full-time basis as a public relations officer for a motor firm. He carries out his duties with the aid of a motorised hand splint, recently acquired his own motor car, has employed a chauffeur and has married a C6 tetraplegic girl who is studying for a degree by correspondence.

(3) A T 5 complete paraplegic as result of a diving accident who is administrative manager of a container depot firm. He drives approximately 25 miles to work each day and leads a very full and active social life.

(4) A T9 complete paraplegic as result of a motor accident when she was the sister in charge of a respiratory intensive care unit. On discharge from the spinal unit she returned to her job and managed well for some months but decided to become an occupational therapist. She enrolled as a student at Stellenbosch University and joined the Conradie Hospital Occupational Therapy Department on qualifying 4 years ago. Her ability has initiated her recent promotion to chief occupational therapist in charge of the department.

(5) A Ti complete paraplegic as result of an astrocytoma of the cord who is a laboratory technician at the Conradie Hospital and the very active and able secretary of the Paraplegic Games Association of South Africa and a very active sportswoman.

All these, and many others like them, have taught us a lesson, in that in the process of rehabilitation decision making should be shared, with the patient as the 
prime decision maker, guided by the team. The opportunity to play a major role in vital decisions about the future sows the seeds of motivation, so often lacking when someone is told what he or she should be doing, so often not what that person wants to be doing. Options can be offered but the final decision should rest with the patient.

Assistance with social integration and adaptation is provided for in South Africa by State departments, provincial and local authorities and private welfare organisations which are social, educational and vocational in nature.

It should be noted that South Africa is not a Welfare State with most social security and resources being supplied by the central government. The S.A. welfare system is in contrast based on a partnership between central government, provincial authorities (similar to United Kingdom county councils) and private welfare organisations. By private welfare organisations is meant those services initiated by community groups and frequently subsidised by central government. Cripple Care Association (Western Cape) is such an organisation.

Before studying the myriad of welfare facilities catering for locomotor disabled in South Africa, it is important to review the problems confronting a disabled person in the community, viz.,

(a) Attitudes to the community;

(b) Architectural barriers;

(c) Living arrangements in the community, in terms of both housing and possibility of attendant's allowance;

(d) Transportation;

(e) Education and employment possibilities;

(f) Cost of appliances;

(g) Pension and income security;

(h) Few recreational facilities.

Welfare services in South Africa are governed by specific legislation, and provided by central government, provincial and local authorities and private welfare organisations:

\section{Overview of Welfare Structure in South Africa Welfare Services}

governed by

National Welfare Act No. I00 of 1978

Social and Associated Workers Act No. I Io of 1978

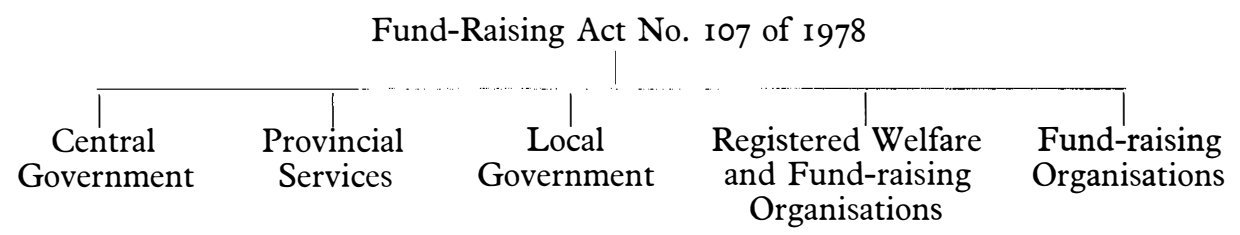

Specific provisions by central government include:

(I) Disability grants for those unable to be gainfully employed;

(2) Sheltered employment workshops for those who are at least 50 per cent productive; 
(3) Subsidisation of protected workshops;

(4) Subsidisation of posts in open labour market;

(5) Special schools for physically disabled or subsidisation thereof;

(6) Subsidisation of residential institutions for locomotor disabled;

(7) Low interest loans for building special facilities;

(8) Rebate of 80 per cent on tariff charged by Customs and Excise on new cars.

Provincial authorities are responsible for the provision of hospitalisation, such as Conradie Hospital, and technical aids. The latter are however, only provided for persons below a certain income bracket.

One of the most pressing needs of any paraplegic or tetraplegic, as with all people, is that of securing a liveable income-whether by way of social security or not. Social security is available for those unable to obtain gainful employment, however, for those who are able to work, they have to transcend the difficulties associated with architectural barriers, prospective employer prejudice and transport difficulties. In addition, in order to retain their physical resources for use in the employment situation, an attendant is frequently necessary to help the paraplegic or tetraplegic to get to work.

In South Africa there is at present no legal enforcement to:

(a) ensure that the physical environment is accessible in terms of architectural barriers or transport;

(b) ensure that employers employ a certain percentage of disabled persons;

(c) provide for attendant's allowance for those who are not able to afford this themselves.

Despite this lack of legal provision, various private welfare organisations are rendering services pertaining to these particular problems, e.g. The Cripple Care Association (Western Cape) has initiated community activity groups where tetraplegics, paraplegics and other locomotor disabled who are not employed in the open labour market or formal sheltered employment, make articles which are marketed via the Cripple Care Product Shop. In addition, they have training workshops where disabled persons can be trained in skills of which they are capable, thereby in some measure overcoming some employer prejudice. Counselling services, loan of mobility aids and a limited transport facility are also provided by this organisation.

The Quadriplegic Association of South Africa have employed an attendant who is being trained, thereby initiating a scheme of attendants for members of their organisation.

Other welfare organisations catering for the needs of the locomotor disabled are the St Giles Association who provide recreational facilities, Cheshire Homes responsible for providing homes for the disabled and the S.A. Sports Association for the Physically Disabled, responsible for sporting facilities.

While there remain difficulties for the paraplegics and the tetraplegics in the South African situation, there have been some outstanding examples of those who have integrated themselves into their local communities. It is hoped that during the International Year of Disabled Persons that the impetus will be provided for the much needed other facilities for all locomotor disabled in South Africa.

\section{SUMMARY}

Rehabilitation of the disabled is a dynamic process which should start from the first day post-injury. Total rehabilitation should include, not only attaining 
maximum function, but also, satisfaction with life in one's own environment. The obstacles created by able-bodied society, are problems that face the disabled person. The right to participate in, and contribute to, all aspects of economic, social and political life is theirs too, as is the right to make decisions about the future. This should not be overlooked, as decision making sows the seeds of motivation. This in turn dictates the measure of success of social reintegration. Assistance is provided in South Africa by various organisations of central government, provincial and local authorities and private welfare organisations. The Cripple Care Association is a private welfare organisation which provides assistance and acts as a link with other relevant organisations. In the Western Cape the number of successfully rehabilitated persons increases and their presence in the community creates an awareness of their needs. This in turn initiates the process of positive change and action.

\section{Dr Key's French summary}

\section{RÉSUMÉ}

La réadaptation de la personne handicapée est un processus dynamique qui devrait commencer dès le premier jour après l'accident. La réadaptation totale devrait inclure non seulement l'obtention d'une fonction maximale mais aussi une vie la plus satisfaisante possible dans l'environnement de la personne. Les obstacles créés par la société sont des problèmes auxquels la personne handicapée doit faire face. Le droit à la participation et à la contribution à tous les aspects, qu'ils soient économiques, sociaux et politiques, est le leur aussi ainsi que la prise de décisions concernant l'avenir. Ceci ne doit pas être méconnu car la possibilité de décision sème les graines de la motivation. En Afrique du Sud, les personnes handicapées peuvent obtenir aides des auprès de différentes organisations du gouvernement central, provincial, des autorités locales ou de groupes d'entre-aide privés. L'Association "Cripple Care" est une oeuvre de bienfaisance privée, qui fournit une assistance et assure la liaison avec d'autres organisations importantes. Dans la partie ouest du Cap le nombre de personnes rééduquées avec succès augmente et leur présence dans la communauté soulève le problème de leurs besoins, d'où la nécessité de la mise en route d'un processus positif de changement et d'action.

\section{ZUSAMMENFASSUNG}

Rehabilitation der Behinderten ist ein Verfahren, welches schon sofort nach der Verletzung geuebt werden soll. Totale Rehabilitation soll nicht nur die Maximale Funktion des Koepers bedeuten, sondern auch ein zufriedenes Leben in der eigenen Umgebung. Schwierigkeiten, die im Umgang mit gesunden Menschen vorkommen, sind Probleme wit welchen der Behinderte konfrontiert wird.

Die Behinderten haben das Recht teilhaben und beitragen zukoenen in allen Aspekten das wirtschaftlichen sowie politischen Lebens. Ebenfalls das Recht ihre eigne Zukunft zu bestimmen. Dieses sollte nicht eubersenen werden da ein eigner Entschluss den Samen zur Motivation saeht.

In Sued Afrika gibt es verschiedene Organisationen die Hilfe leisten. Z. B. provinziale so wie hiesige Authoritaeten ebenfalls private Wolfahrts gruppen. Die "Cripple Care Organisation" ist eine private Wolfahrts-organisation welche Hilfe anbietet und auch die verbindung zwischen anderen Organisationen herstellt.

Hier im Westen 'Cape' nimmt die nummer der erfolgriech rehabilitierten Personnen von Jahr zu Jahr zu, und deren Gegenwart in unserer Gemeinde verschafft ein Verstaendniss feur die Bedeurfnisse der rehabilitierten Menschen. Dieses wiererum verursacht das Verfahren zur positiven Handlung. 